\title{
Pengaruh Disiplin dan Motivasi Kerja Terhadap Kinerja Pegawai Satuan Polisi Pamong Praja (Satpol PP) Kabupaten Karawang
}

\author{
Neneng Sofiyanti ${ }^{(1)}$, Achmad Nawawi ${ }^{(2)}$ \\ Universitas Singaperbangsa Karawang \\ Sofiyanz2909@gmail.com \\ Achmad.nawawi@staff.unsika.ac.id
}

\begin{abstract}
Abstrak
Berdasarkan studi pendahuluan ditemukan bahwa kinerja pegawai Satuan Polisi Pamong Praja Kabupaten Karawang belum optimal. Beberapa faktor penyebab yang ditemukan, diduga disiplin dan motivasi kerja merupakan faktor penting yang paling dominan pengaruhnya. Oleh karenanya masalah yang dirumuskan meliputi bagaimana disiplin, motivasi kerja dan kinerja pegawai Satpol PP Kabupaten karawang. Apakah terdapat korelasional antara disiplin dan motivasi kerja serta pengaruh dari disiplin dan motivasi kerja terhadap kinerja pegawai Satpol PP Kabupaten Karawang baik secara parsial maupun simultan.

Tujuan penelitian untuk memperoleh bukti-bukti empirik dan menemukan kejelasan fenomena serta kesimpulan tentang hubungan korelasional antara disiplin dan motivasi kerja serta pengaruh dari disiplin dan motivasi kerja terhadap kinerja pegawai Satpol PP Kabupaten Karawang baik secara parsial maupun simultan. Penelitian ini menggunakan metode deskriptif survey dan eksplanatory survey. Teknik pengambilan sampel menggunakan metode sensus. Analisis data untuk menggambarkan masing-masing variabel menggunakan rentang skala. Sedangkan untuk menggambarkan pengaruh variabel disiplin dan motivasi kerja menggunakan analisis jalur.
\end{abstract}

Hasil analisis data penelitian menunjukkan bahwa disiplin di Satpol PP Kabupaten Karawang berada pada skala cukup tinggi, motivasi Kerja berada pada skala tinggi, kinerja pegawai berada pada skala tinggi, terdapat hubungan secara korelasional antara disiplin dan motivasi kerja, terdapat pengaruh secara parsial dan simultan dari disiplin dan motivasi kerja terhadap kinerja pegawai Satpol PP Kabupaten Karawang.

Kata kunci : Disiplin, Motivasi Kerja, Kinerja Pegawai.

The Influence of Discipline and Work Motivation to Officer Satuan Polisi Pamong Praja (Satpol PP) Of Regency Karawang

\begin{abstract}
Based on preliminary studies was found that Officer Performance is not yet optimal. Of the many factors that cause is found, discipline, and work motivation is the most dominant factor of influence. Therefore the formulated problem include how discipline, work motivation, and officer Satpol PP Performance of Regency Karawang. Whether there is a correlation between discipline and work motivation and influences discipline and work motivation to officer Satpol PP performance of Regency Karawang by partial and simultan
\end{abstract}

The research of target is obtaining empiric evidence and finding clarity of phenomenon and also conclusion about the corelational between discipline and work motivation, the influence of discipline and work motivation to officer Satpol PP performance of Regency Karawang. This research uses descriptive survey and explanatory survey method. The sampling technique was used sensus method. Data analysis techniques is to expose each variable we, it used range scale. Data analysis technique used correlation analysis technique variables and Path Analysis Technique, to expose the influence of discipline and work motivation. The results of data analysis showed that discipline at Satpol PP of Regency Karawang is high enough, work motivation is high, Officer Performance is high, discipline and work motivation influences directly by partial and simultan to officer performance at Satpol PP Regency Karawang.

Keywords : Discipline, Work Motivation, Officer Performance 


\section{Pendahuluan}

Dalam rangka mewujudkan hal tersebut, perlu kiranya memperhatikan kualitas Sumber Daya Manusia (SDM) yang handal, terlatih, serta terampil dan peka terhadap tuntutan masyarakat. Hanya saja, untuk menghasilkan sumber daya manusia yang kinerjanya atau prestasi kerjanya tinggi seorang pegawai tidak hanya perlu memiliki keterampilan, tetapi ia juga harus memiliki keinginan dan kegairahan untuk berprestasi tinggi. Salah satu upaya yang dapat diakukan untuk meningkatkan kemampuan SDM atau pegawai adalah dengan menciptakan iklim yang dapat memotivasi pegawai untuk meningkatkan kinerja atau prestasi kerjanya, dalam hal ini pemahaman mengenai kebutuhan atau keinginan para pegawai.

Kinerja merupakan suatu yang lazim digunakan untuk memantau produktivitas kerja sumber daya manusia baik yang berorientasi produksi barang, jasa maupun pelayanan. Kinerja pegawai dapat dipengaruhi oleh dua faktor yaitu faktor eksternal dan faktor internal pegawai. Faktor eksternal yaitu faktor-faktor yang mempengaruhi kinerja seseorang yang berasal dari lingkungan seperti perilaku, sikap, dan tindakan-tindakan rekan kerja, bawahan atau pimpinan, fasilitas kerja dan iklim organisasi. Sementara faktor internal meliputi faktor individu (kemampuan dan keahlian, latar belakang serta demografi) dan faktor pskologis meliputi persepsi, attitude, personality, pembelajaran dan motivasi (Mangkunegara, 2009: 16).

Seperti yang tercantum dalam realita-news.com, Anggota Badan Anggaran (banggar) DPRD Kabupaten Karawang menyatakan bahwa banyak pelanggaran Perda tanpa tindakan maupun sanksi yang dilakukan Satpol PP. Contohnya pelanggaran Perda Nomor 2 Tahun 2013 tentang Rencana Tata Ruang Wilayah Kabupaten Karawang. Aneh, jika aparatur penegak Perda hanya menunggu laporan atau perintah dari OPD lain terkait melakukan penertiban terhadap pelanggar Perda (www.realita-news.com). Kondisi obyektif menunjukan bahwa sikap mental yang taat dan patuh terhadap tata kehidupan atau norma, etik dan kaidah yang diatur dalam organisasi kurang dimiliki oleh sebagian pegawai dilingkungan Satuan Polisi Pamong Praja, memang tidak semua pegawai mampu melaksanakan tugas dan fungsinya secara optimal disebabkan karena persoalan yang komplek misalnya kepuasan kerja, penghargaan, keharmonisan, komunikasi dan lain-lain yang ada kaitannya dengan banyak persolan antara lain , masih banyak pegawai yang terlambat masuk kantor, mangkir/tidak masuk kerja,masih ada pegawai yang tidak memahami tugas, masih adanya pemberian penghargaan yang kurang tepat sasaran, motivasi kerja Sat Pol PP masih rendah, 
disiplin kerja masih rendah, kinerja pegawai Sat Pol PP masih relatif rendah, harmonisasi atau sinergitas antar pegawai belum terjadi.

Kinerja pegawai dapat dipengaruhi oleh tingkat disiplin. Hal ini sesuai dengan penelitian Wahyuningrum (2009:127) yang menyebutkan bahwa terdapat hubungan yang positif antara disiplin kerja dengan kinerja. Zaeni (2012) dengan penelitiannya yang berjudul "Pengaruh Disiplin dan Motivasi Kerja terhadap Kinerja Pegawai Kantor Urusan Agama Kabupaten Karawang". Zaeni menyimpulkan bahwa disiplin dan motivasi kerja berpengaruh secara langsung terhadap kinerja pegawai. Endang Sumarna (2007) menyimpulkan bahwa disiplin dan kepuasan kerja memberikan kontribusi positif terhadap kinerja pegawai. Sedangkan Kuswanda (2006) dalam penelitiannya yang berjudul "Pengaruh Kemampuan Kerja, Motivasi Kerja dan Disiplin Kerja terhadap Kinerja Pegawai Dekonsentrasi dan Tugas Perbantuan SETDA Provinsi Jawa Barat”, menyimpulkan bahwa kemampuan kerja, motivasi kerja dan disiplin kerja berpengaruh terhadap kinerja pegawai. Ridwan (2012) dalam penelitiannya yang berjudul "Peran Kepemimpinan dan Disiplin kerja terhadap Kinerja Guru", menyimpulkan bahwa peran kepemimpinan dan disiplin kerja berpengaruh terhadap kinerja guru.

Permasalahan yang sering dilingkungan Sat Pol PP terkait masalah disiplin kerja adalah masih banyak pegawai yang melakukan pelanggaran disiplin dalam hal jam datang dan pulang kerja. Jam kerja untuk hari Senin-Kamis adalah pukul 07.30 s.d 16.00, tetapi masih banyak yang hadir setelah jam tersebut dan pulang sebelum waktunya. Ketepatan waktu dalam melaksanakan tugas yang diberikan masih belum berjalan dengan optimal, masih banyak pegawai yang belum memahami tugas dan pelanggaran terhadap prosedur kerja.Motivasi banyak dipengaruhi emosi. Seseorang yang memiliki motivasi tinggi akan selalu menerima kritik dan saran dari luar serta telah mempersiapkan diri secara matang dengan hal-hal yang akan terjadi dilapangan (Iskandar, 2002:2).

Hasibuan dalam Nawawi (2006:64) menyatakan bahwa hasil kerja atau prestasi merupakan gabungan dari tiga faktor terdiri dari minat dalam bekerja, penerimaan delegasi tugas, dan tingkat motivasi seorang pekerja. Hal ini sesuai dengan penelitian Hidayat (2012) yang berjudul "Pengaruh Kepemimpinan dan Motivasi Kerja terhadap Kinerja Karyawan PT KIA", yang menyimpulkan bahwa kepemimpinan, dan motivasi kerja berpengaruh terhadap Kinerja. Penelitian Gusmana (2008) menyimpulkan bahwa budaya organisasi, disiplin kerja, dan motivasi kerja berpengaruh terhadap Kinerja.Sedangkan Handayaningsih (2006) 
menyimpulkan bahwa kepemimpinan, motivasi, disiplin kerja,pengawasan, berpengaruh signifikan terhadap produktivitas kerja pegawai.

. Berdasarkan latar belakang diatas maka perlu penelitian berjudul "Pengaruh Disiplin Dan Motivasi Kerja Terhadap Kinerja Pegawai Satuan Polisi Pamong Praja Kabupaten Karawang” .

\section{Tinjauan pustaka}

\subsubsection{Pengertian Manajemen}

Manajemen merupakan praktik spesifik yang mengubah sekumpulan orang menjadi kelompok yang efektif, berorientasi pada tujuan, dan produkstif (Wibowo, 2010 : 1). Stoner dan Freeman dalam Wibowo (2010:2) berpandangan bahwa manajemen merupakan sutu proses menggunakan sumber daya oranisasi untuk mencapai tujuan organisasi melalui fungsi planning, decision making, organizing, leading, dan controlling. Sedangkan menurut Stoner dalam Handoko (2001) Manajemen merupakan proses perencanaan, pengorganisasian, pengarahan, dan pengawasan usaha-usaha para anggota organisasi dan penggunaan sumber daya-sumber daya organisasi lainnya agar mencapai tujuan organisasi yang telah ditetapkan.

\subsubsection{Pengertian Manajemen Sumber Daya Manusia (MSDM)}

Sedarmayanti (2010:13-14) menyatakan bahwa MSDM adalah kebijakan dan praktik menentukan aspek manusia atau sumber daya manusia dalam posisi manajemen, termasuk merekrut, menyaring, melatih, memberi penghargaan, dan penilaian.

Siagian (2009:135) menyatakan bahwa kemampuan pemimpin dan seluruh jajaran satuan kerja yang bertanggungjawab untuk mengelola sumber daya manusia dalam suatu organisasi, terlihat antara lain dalam terselenggaranya semua fungsi guna mendukung kegiatan semua komponen organisasi yang bersangkutan.

\subsubsection{Disiplin Kerja}

\subsubsection{Pengertian Disiplin Kerja}

Keith Davis dalam Mangkunegara (2009:129) mengemukakan bahwa " Dicipline is management action to enforce organization standards”. Berdasarkan pendapat Keith Davis, disiplin kerja dapat diartikan sebagai pelaksanaan manajemen untuk memperteguh pedomanpedoman organisasi. Sedarmayanti (2010: 381) mengatakan bahwa disiplin adalah kondisi untuk melakukan koreksi atau menghukum pegawai yang melanggar ketentuan atau prosedur yang telah ditetapkan organisasi. Heidjarachman dan Husnan (2002:15) mengungkapkan 
disiplin adalah setiap perseorangan dan juga kelompok yang menjamin adanya kepatuhan terhadap perintah dan berinisiatif untuk melakukan suatu tindakan yang diperlukan seandainya tidak ada perintah.

Menurut Handoko (2001:208) disiplin adalah kegiatan manajemen untuk menjalankan standar-standar organisasional. Suatu kedisiplinan penting bagi organisasi, sebab adanya kedisiplinan akan ditaati oleh sebagain besar pegawai dan diharapkan pekerjaan akan dilakukan secara efektif. Dalam penerapannya disiplin lebih ditekankan pada unsur kesadaran dan penyesuaian diri secara sukarela bukan atas dasar paksaan.

Senada dengan pendapat di atas, Fathoni (2006 : 172) mengartikan disiplin sebagai : "Kesadaran dan kesediaan seseorang mentaati semua peraturan organisasi dan norma-norma sosial yang berlaku". Selanjutnya Fathoni menjelaskan bahwa : "Kedisiplinan diartikan bilamana karyawan selalu datang dan pulang tepat pada waktunya, mengerjakan semua pekerjaannya dengan baik, mematuhi semua peraturan perusahaan dan norma-norma sosial yang berlaku

Pendisiplinan kerja pegawai adalah suatu bentuk pelatihan yang berusaha memperbaiki dan membentuk pengetahuan, sikap dan perilaku pegawai sehingga para pegawai tersebut secara sukarela berusaha bekerja secara kooperatif dengan para pegawai yang lain serta meningkatkan prestasi kerjanya (Siagian, 2009:80). Mangkunegara (2009:129) membagi 2 bentuk disiplin kerja, yaitu disiplin preventif, dan disiplin korektif.

Indikator yang digunakan dari variabel disiplin kerja dalam penelitian ini mengacu pada Fathoni (2006 : 172) yang menggunakan tiga kriteria pengukuran disiplin, yaitu : tingkat ketepatan waktu, tingkat kepatuhan terhadap peraturan, dan tingkat kesadaran dalam bekerja.

\subsubsection{Motivasi Kerja}

\subsubsection{Pengertian Motivasi Kerja}

Abraham Sperling dalam Mangkunegara (2009:93) mengemukakan bahwa "Motive is defined as a tendency to activity, started by a drive an enden by adjustment. The adjustment is said to satisfy the motive.Robert Heller dalam Wibowo (2010:378) menyatakan bahwa motivasi adalah keinginan untuk bertindak. Sedangkan Robbins dalam Wibowo (2010:378379) menyatakan motivasi sebagai proses yang menyebabkan intensitas (intensity), arah (direction), dan usaha terus menerus (persistence) individu mencapai tujuan. Intensitas menunjukkan seberapa keras orang berusaha. Motivasi dapat juga diartikan sebagai proses untuk mencoba mempengaruhi orang atau orang-orang yang dipimpinnya agar melakukan 
pekerjaan yang diinginkan, sesuai dengan tujuan tertentu yang telah ditetapkan lebih dahulu (Uno, 2011:1)

Hani Handoko (2001) mengemukakan istilah Motivasi diartikan sebagai keadaan dalam pribadi seseorang yang mendorong keinginan individu untuk melakukan kegiatankegiatan tertentu guna mencapai tujuan. Berdasarkan pendapat para ahli diatas dapat disimpulkan bahwa motivasi merupakan dorongan yang terdapat dalam diri seseorang untuk berusaha mengadakan perubahan tingkah laku yang lebih baik dalam memenuhi kebutuhannya.

\subsubsection{Teori Motivasi}

Menurut Mangkunegara (2009:61-62) terdapat beberapa prinsip dalam memotivasi kerja pegawai yaitu Prinsip partisipasi dan prinsip mngakui adanya bawahan. Prinsip pendelegasian wewenang, Prinsip memberi perhatian

Dalam upaya memotivasi kerja pegawai perlu diberikan kesempatan ikut berpartisipasi dalam menentukan tujuan yang akan dicapai oleh pemimpin.

Beberapa teori motivasi yang tercantum dalam Siagian (2009:103-108) diantaranya Teori motivasi menurut Maslow menurut Maslow, manusia mempunyai sejumlah kebutuhan yang diklasifikasikannya pada lima tingkatan atau hierarki yaitu kebutuhan fisiologis, Kebutuhan akan rasa aman, Kebutuhan sosial, Kebutuhan yang mencerminkan harga diri, dan Kebutuhan aktualisasi diri.

\subsubsection{Dimensi Motivasi Kerja}

Uno (2009:72) menyebutkan empat dimensi motivasi kerja yang terdiri dari Tanggung jawab, prestasi, Pengembangan diri dan kemandirian.

\subsubsection{Kinerja}

\subsubsection{Pengertian Kinerja}

Kinerja menurut kamus umum bahasa Indonesia adalah asal kata dasar kerja mempunyai arti "perbuatan melakukan sesuatu" (Poerwadarminta, 2002:492). Faustino Cardoso Gomes dalam Mangkunegara (2009:9) mengemukakan definisi kinerja sebagai : "ungkapan seperti output, efisiensi serta efektivitas sering dihubungkan dengan produktivitas". Armstrong dan Baron dalam Wibowo (2010:7) menyatakan bahwa kinerja merupakan hasil pekerjaan yang mempunyai hubungan kuat dengan tujuan strategis 
organisasi, kepuasan konsumen, dan memberikan kontribusi pada ekonomi. Menurut Edi Sutrisno (2007: 170), kinerja atau prestasi kerja adalah bagaimana seseorang diharapkan dapat berfungsi dan berperilaku sesuai dengan tugas yang telah dibebankan kepadanya. Selanjutnya Mangkunegara (2009:9) menyatakan bahwa: "kinerja (prestasi kerja) adalah hasil kerja secara kualitas dan kuantitas yang dicapai oleh seseorang dalam melaksanakan tugasnya sesuai dengan tanggung jawab yang diberikan kepadanya”.

\subsubsection{Teori Kinerja}

Menurut Henry Simamora dalam Mangkunegara (2009:14) kinerja dipengaruhi oleh tiga faktor yaitu:

1. Faktor individual yang terdiri dari kemampuan dan keahlian, latar belakang, dan demografi.

2. Faktor psikologis yang terdiri dari persepsi, attitude, personality, pembelajaran, dan motivasi.

3. Faktor organisasi yang terdiri dari sumber daya, kepemimpinan, penghargaan, struktur dan job design.

Menurut A. Dale Timple dalam Mangkunegara (2009:15), faktor kinerja terdiri dari faktor internal dan faktor eksternal. Faktor internal yaitu faktor yang dihubungkan dengan sifat-sifat seseorang. Leon C. Mengginson dalam Mangkunegara (2009: 9-10) adalah sebagai berikut: "Penilaian prestasi kerja adalah suatu proses yang digunakan pimpinan untuk menentukan apakah seorang pegawai melakukan pekerjaannya sesuai dengan tugas dan tanggungjawabnya. Menurut Mangkunegara (2009: 10-11) tujuan penilaian kinerja adalah untuk memperbaiki atau meningkatkan kinerja organisasi melalui peningkatan kinerja dari SDM organisasi.

\subsection{Hasil Penelitian Terdahulu}

Hasil penelitian terdahulu yang relevan dapat dilihat pada tabel 2.1.

Tabel 2.1

\section{Penelitian terdahulu yang relevan}

\begin{tabular}{|l|l|l|l|}
\hline Penelitian sebelumnya & Hasil Penelitian & Persamaan & Perbedaan \\
\hline Kuswanda (2006) & Kemampuan & Variabel Kinerja & - Lokasi penelitian \\
\hline
\end{tabular}




\begin{tabular}{|c|c|c|c|}
\hline $\begin{array}{l}\text { "Pengaruh Kemampuan } \\
\text { Kerja, Motivasi Kerja } \\
\text { dan Disiplin Kerja } \\
\text { terhadap Kinerja } \\
\text { Pegawai Dekonsentrasi } \\
\text { dan Tugas Perbantuan } \\
\text { SETDA Provinsi Jawa } \\
\text { Barat" }\end{array}$ & $\begin{array}{l}\text { Kerja, Motivasi } \\
\text { Kerja dan } \\
\text { Disiplin Kerja } \\
\text { berpengaruh } \\
\text { terhadap } \\
\text { Kinerja Pegawai }\end{array}$ & 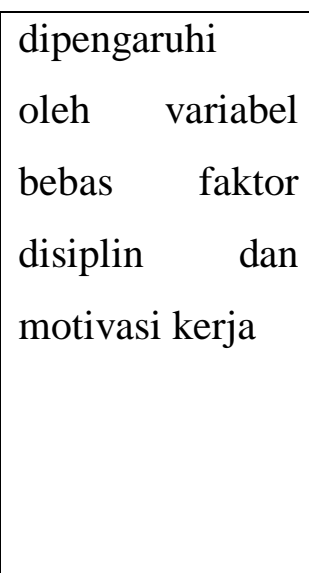 & $\begin{array}{l}\text { di Sat Pol PP } \\
\text { Kabupaten } \\
\text { Karawang }\end{array}$ \\
\hline $\begin{array}{l}\text { Handayaningsih (2006) } \\
\text { "Pengaruh } \\
\text { Kepemimpinan, } \\
\text { Motivasi, Disiplin } \\
\text { Kerja Dan Pengawasan } \\
\text { Terhadap Produktivitas } \\
\text { Kerja Pegawai } \\
\text { Kecamatan Wilayah } \\
\text { Kabupaten Wonogiri. }\end{array}$ & $\begin{array}{l}\text { kepemimpinan, } \\
\text { motivasi, } \\
\text { disiplin } \\
\text { kerja,pengawasa } \\
\mathrm{n}, \quad \text { berpengaruh } \\
\text { signifikan } \\
\text { terhadap } \\
\text { produktivitas } \\
\text { kerja pegawai . }\end{array}$ & $\begin{array}{l}\text { Variabel } \\
\text { motivasi dan } \\
\text { disiplin sebagai } \\
\text { variabel bebas }\end{array}$ & $\begin{array}{l}\text { - Variabel kinerja } \\
\text { pegawai sebagai } \\
\text { variabel dependen. } \\
\text { - Tempat penelitian } \\
\text { dilakukan di Sat } \\
\text { Pol PP Kab. } \\
\text { Karawang }\end{array}$ \\
\hline $\begin{array}{l}\text { Hidayat (2012) “ } \\
\text { Pengaruh } \\
\text { Kepemimpinan } \\
\text { Motivasi } \\
\text { terhadap } \\
\text { Karyawan PT KIA” }\end{array}$ & $\begin{array}{l}\text { Kepemimpinan } \\
\text { dan motivasi } \\
\text { kerja } \\
\text { berpengaruh } \\
\text { secara terhadap } \\
\text { kinerja }\end{array}$ & $\begin{array}{l}\text { Variabel Kinerja } \\
\text { dipengaruhi } \\
\text { Variabel } \\
\text { motivasi dan } \\
\text { disiplin sebagai } \\
\text { variabel bebas }\end{array}$ & $\begin{array}{l}\text { 1. Variabel kinerja } \\
\text { dipengaruhi oleh } \\
\text { variabel disiplin } \\
\text { 2. Tempat } \\
\text { penelitian } \\
\text { dilakukan di Sat } \\
\text { Pol PP Kab. } \\
\text { Karawang }\end{array}$ \\
\hline $\begin{array}{l}\text { Victor Obule Ebuara } \\
\text { and Maurice Ayodele } \\
\text { Coker (2012) } \\
\text { Influence of Staff } \\
\text { Discipline and Attitude } \\
\text { to work On Job } \\
\text { Satisfaction Lectures in }\end{array}$ & $\begin{array}{l}\text { Disiplin staff } \\
\text { mempengaruhi } \\
\text { kepuasan kerja }\end{array}$ & $\begin{array}{l}\text { Variabel disiplin } \\
\text { sebagai variable } \\
\text { bebas }\end{array}$ & $\begin{array}{l}\text { 1. Variabel } \\
\text { motivasi kerja } \\
\text { sebagai variable } \\
\text { bebas } \\
\text { 2. Variabel kinerja } \\
\text { sebagai variable } \\
\text { terikat }\end{array}$ \\
\hline
\end{tabular}




\begin{tabular}{|l|l|l|l|}
\hline \multicolumn{2}{|l|}{$\begin{array}{l}\text { Tertiary Institutions in } \\
\text { Cross River State" }\end{array}$} & & \\
\hline Widyaningrum (2011) & Motivasi dan & Kinerja pegawai & 1. Kinerja \\
"Influence dipengaruhi \\
Motivation and Culture & organisasi & dipengaruhi & disiplin sebagai \\
On Organizational & mempengaruhi & sebagai variable & variable bebas \\
Commitmen and & komitmen & bebas & 2. Tempat \\
Performance & penelitian \\
Employee of Medical & kinerja pegawai & & dilakukan di Sat \\
Services" & & & Pol PP Kab. \\
& & & Karawang \\
\hline
\end{tabular}

Disarikan dari berbagai sumber, 2013

\section{Metode penelitian}

\subsection{Metode Yang Digunakan}

Tujuan studi dari penelitian ini adalah deskriptif dan verifikatif. Metode penelitian yang digunakan adalah penelitian survey dan metode explanatory survey. Menurut Sugiyono (2010:10) metode explanatory survey merupakan metode penelitian yang bermaksud menjelaskan kedudukan variabel-variabel yang diteliti serta pengaruh antara satu variabel dengan variabel yang lain.

\subsection{Operasionalisasi Variabe}

Variabel penelitian ini dapat diidentifikasikan seperti dalam tabel 3.1

\section{Tabel 3.1}

\section{Operasionalisasi variabel}

\begin{tabular}{|c|c|c|c|}
\hline Variabel & Konsep & Dimensi & Indikator \\
\hline \multirow[t]{3}{*}{$\begin{array}{l}\text { Disiplin } \\
\left(X_{1}\right)\end{array}$} & \multirow{3}{*}{$\begin{array}{l}\text { Disiplin kerja } \\
\text { adalah suatu sikap } \\
\text { pegawai, tingkah } \\
\text { laku pegawai, dan } \\
\text { perbuatan pegawai } \\
\text { yang sesuai dengan } \\
\text { peraturan organisasi } \\
\text { baik secara tertulis } \\
\text { maupun tidak }\end{array}$} & Ketepatan Waktu & $\begin{array}{l}\text { Ketepatan waktu dalam melaksanakan } \\
\text { tugas } \\
\text { Ketepatan waktu dalam kehadiran }\end{array}$ \\
\hline & & $\begin{array}{l}\text { Kepatuhan } \\
\text { peraturan }\end{array}$ & $\begin{array}{l}\text { Ketaatan terhadap pimpinan } \\
\text { Ketaatan terhadap prosedur dan } \\
\text { metode kerja } \\
\text { Ketaatan terhadap pakaian dinas dan } \\
\text { atribut }\end{array}$ \\
\hline & & Kesadaran & Paham tugas \\
\hline
\end{tabular}




\begin{tabular}{|c|c|c|c|}
\hline & $\begin{array}{l}\text { tertulis. } \\
\text { (Fathoni, } 2006 \text { : } \\
\text { 172) }\end{array}$ & bekerja & Pelaksanaan tugas \\
\hline \multirow[t]{4}{*}{$\begin{array}{l}\text { Motivasi } \\
\text { Kerja } \\
\left(\mathrm{X}_{2}\right)\end{array}$} & \multirow{4}{*}{$\begin{array}{l}\text { motivasi merupakan } \\
\text { dorongan yang } \\
\text { terdapat dalam diri } \\
\text { seseorang untuk } \\
\text { berusaha } \\
\text { mengadakan } \\
\text { perubahan tingkah } \\
\text { laku yang lebih baik } \\
\text { dalam memenuhi } \\
\text { kebutuhannya. } \\
\text { Uno (2009:72) }\end{array}$} & $\begin{array}{l}\text { Tanggung } \\
\text { jawab }\end{array}$ & $\begin{array}{l}\text { Hadir di tempat kerja setiap hari tepat } \\
\text { waktu } \\
\text { Merasa gelisah jika tugas belum } \\
\text { selesai } \\
\text { Mengerjakan tugas tepat waktu }\end{array}$ \\
\hline & & Prestasi & $\begin{array}{l}\text { Berusaha memperlihat kan prestasi } \\
\text { kerja } \\
\text { Bekerja keras melebihi target } \\
\text { Mampu menyelesaikan setiap masalah }\end{array}$ \\
\hline & & Pengembangan diri & $\begin{array}{l}\text { Mengikuti setiap pelatihan } \\
\text { Bangga mendapat tugas baru } \\
\text { Berusaha untuk meningkatkan } \\
\text { kemampuan diri } \\
\text { Selalu melakukan perubahan atau } \\
\text { inovasi terbaik }\end{array}$ \\
\hline & & Kemandirian & $\begin{array}{l}\text { Menyelesaikan masalah tanpa } \\
\text { menunggu instruksi } \\
\text { Mengembangkan kreativitas }\end{array}$ \\
\hline
\end{tabular}

\subsection{Sumber dan Cara Penentuan Data/Informasi}

\subsubsection{Sumber Data}

Sumber data dalam penelitian ini sumber data primer dan data sekunder. Data primer bersumber dari pemberi data secara langsung yaitu dari sampel yang diambil di Satuan Polisi Pamong Praja (Sat Pol PP) Kabupaten Karawang, sedangkan data sekunder berupa dokumen yang berhubungan dengan penelitian.

\subsubsection{Cara Penentuan Data/Informasi}

\subsubsection{Populasi}

Populasi penelitian yang diteliti adalah Pegawai Pada Satuan Polisi Pamong Praja (Sat Pol PP) Kabupaten Karawang sebanyak 98 orang (sumber: Urusan Kepegawaian Sat Pol PP Kab. Karawang, 2012).

\subsubsection{Sampel}


Berdasarkan jumlah populasi Satuan Polisi Pamong Praja (Sat Pol PP) Kabupaten Karawang sebanyak 98 orang, dengan menggunakan metode sensus yaitu populasi sama dengan sampel maka di dapat jumlah sampel sebanyak 98 orang. Menurut Arikunto (2006) jika jumlah subjeknya kurang dari 100, maka lebih baik semua subyeknya diteliti, sehingga penlitiannya merupakan penelitian populasi, karena sampelnya meliputi semua subyek yang terdapat didalam populasi.

\subsection{Uji Keabsahan Data}

\section{Uji Validitas}

Validitas adalah suatu ukuran yang menunjukkan tingkat-tingkat kevalidan atau kesahihan suatu instrumen. Suatu instrumen yang valid valid atau sahih mempunyai validitas tinggi. Sebaliknya, instrumen yang kurang valid berarti memiliki validitas rendah (Arikunto, 2006:168). Untuk pengujian ini digunakan rumus korelasi product moment (Arikunto, 2006: 170) sebagai berikut :
a. ${ }^{r_{x y}}=\frac{\mathrm{N} \Sigma X Y-(\Sigma X)(\Sigma Y)}{\sqrt{\left\{N \sum X^{2}-(\Sigma X)^{2}\right\}\left\{N \sum Y^{2}-(\Sigma Y)^{2}\right\}}}$

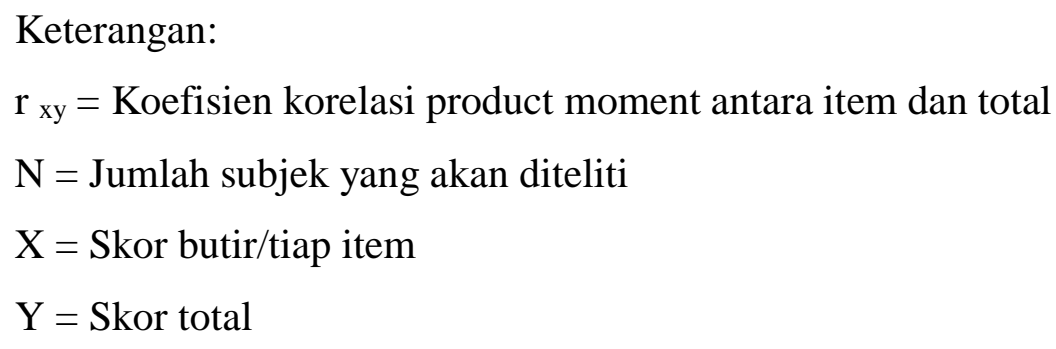

(Arikunto, 2006: 170).

\section{Uji Reliabilitas}

Reliabilitas adalah tingkat kemampuan suatu instrumen penelitian untuk dapat mengukur suatu variabel secara berulangkali dan mampu menghasilkan informasi atau data yang sama atau sedikit sekali bervariasi. Dengan kata lain instrumen tersebut mampu menunjukkan keakuratan, kestabilan dan konsistensi dalam menghasilkan data dari variabel yang diukur (Arikunto, 2006:171). 


\section{Uji Normalitas}

Uji normalitas digunakan dalam penelitian adalah untuk mengetahui apakah variabel dependen, independen atau keduanya berdistribusi normal, mendekati normal atau tidaknya dengan rumus :

$$
\mathrm{X}^{2}=\Sigma \frac{\mathrm{Oi}^{2}}{E i}-\mathrm{n}
$$

untuk mengetahui apakah data tersebut mengikuti sebaran normal dapat dilakukan dengan berbagai metode, diantaranya metode Kolmogorov-Smirnov. Sebuah data bisa dikatakan normal atau tidak, jika p-value > 0,05 (Sudjana,2005:273)

\subsection{Transformasi data ordinal menjadi data interval}

Data dinaikan menjadi data interval dengan method of succesive interval (MSI). Merubah data ordinal menjadi skala interval berurutan (Method of Successive Interval).

$$
\mathrm{SV}=\frac{\text { den sity at lowerlimit }- \text { den sity at upperlimit }}{\text { area underofferlimit }- \text { underlowerlimit }}
$$

\section{Hasil penelitian}

\section{Profil Responden}

Responden dalam penelitian ini sampel pegawai Satuan Polisi Pamong Praja Kabupaten Karawang yang berjumlah 98 orang dengan karakteristik sebagai berikut :

\section{Tabel 4.1}

\section{Jumlah Responden Berdasarkan Masa Kerja}

\begin{tabular}{|l|l|l|l|}
\hline No. & Masa Kerja & Jumlah & Persentase \\
\hline 1 & $\leq 3$ tahun & 18 & $18,37 \%$ \\
\hline 2 & $3<\mathrm{X} \leq 6$ tahun & 7 & $7,14 \%$ \\
\hline 3 & $6<\mathrm{X} \leq 9$ tahun & 10 & $10,20 \%$ \\
\hline 4 & $9<\mathrm{X} \leq 12$ tahun & 28 & $28,57 \%$ \\
\hline 5 & $>12$ tahun & 35 & $35,71 \%$ \\
\hline & Jumlah & 98 & $100 \%$ \\
\hline
\end{tabular}

Sumber :Hasil pengolahan data, 2013

Tabel 4.1 menginformasikan bahwa masa kerja responden yang paling banyak adalah

$>12$ tahun yaitu sebanyak 35 orang $(35,71 \%)$. 
Tabel 4.2

\section{Jumlah Responden Berdasarkan Pendidikan}

\begin{tabular}{|l|l|l|l|}
\hline No. & Pendidikan & Jumlah & Persentase \\
\hline 1 & SMP/SMA & 35 & $35,71 \%$ \\
\hline 2 & DI/DII/DIII & 6 & $6,12 \%$ \\
\hline 3 & S1 & 49 & $50,0 \%$ \\
\hline 4 & S2 & 8 & $8,16 \%$ \\
\hline & Jumlah & 98 & $100 \%$ \\
\hline
\end{tabular}

Sumber :Hasil pengolahan data, 2013

Berdasarkan tabel 4.2 di atas terlihat bahwa pendidikan responden yang paling banyak adalah setingkat S1 yaitu berjumlah 49 orang (50,0\%). Hal ini menunjukkan bahwa sebagian besar responden berpendidikan tinggi.

\section{Tabel 4.3}

\section{Jumlah Responden Berdasarkan Jenis Kelamin}

\begin{tabular}{|l|l|l|l|}
\hline No. & Jabatan & Jumlah & Persentase \\
\hline 1 & Laki-laki & 80 & $81,63 \%$ \\
\hline 2 & Perempuan & 18 & $18,37 \%$ \\
\hline & Jumlah & 98 & $100 \%$ \\
\hline
\end{tabular}

Sumber :Hasil pengolahan data, 2013

Berdasarkan tabel 4.3 di atas diketahui bahwa jumlah responden laki-laki $(81,63 \%)$ lebih besar dibandingkan perempuan $(18,37 \%)$.

Reliabilitas untuk kuisioner masing-masing variabel dapat dapat dilihat pada tabel 4. 7 dibawah ini.

\section{Tabel 4.7}

Reliabilitas

\begin{tabular}{|l|l|l|l|}
\hline Variabel & $\mathbf{R}_{\text {Hitung }}$ & $\mathbf{R}_{\text {Kritis }}$ & Kriteria \\
\hline Disiplin $\left(\mathrm{X}_{1}\right)$ & 0,867 & 0,5 & Reliabel \\
\hline Motivasi kerja $\left(\mathrm{X}_{2}\right)$ & 0,887 & 0,5 & Reliabel \\
\hline Kinerja Pegawai (Y) & 0,859 & 0,5 & Reliabel \\
\hline
\end{tabular}

Sumber : Hasil pengolahan data, 2013 
Tabel 4.8

Uji Normalitas Instrumen

\begin{tabular}{|l|l|l|l|}
\hline \multirow{2}{*}{ Variabel } & \multicolumn{2}{|l|}{ Kolmogorov-Smirnov } & \multirow{2}{*}{ Kesimpulan } \\
& p-value & A & \\
\hline Disiplin $\left(\mathrm{X}_{1}\right)$ & 1,142 & \multirow{2}{*}{0,05} & Dist. Normal \\
& 1.345 & & Dist. Normal \\
& 1,012 & Dist. Normal \\
\hline Kinerja Pegawai (Y) & & \\
\hline \multicolumn{2}{|l}{ Sumber : Hasil Pengolahan Data, 2013} &
\end{tabular}

Tabel di atas menunjukkan bahwa semua variabel mengikuti sebaran data normal karena nilai $\mathrm{p}$-value $>0,05$.

\subsection{Hasil Analisis dan Pembahasan}

\subsubsection{Analisis Deskriptif}

\section{Disiplin di Satuan Polisi Pamong Praja Kabupaten Karawang}

Gambaran mengenai disiplin di Satuan Polisi Pamong Praja Kabupaten Karawang dapat dilihat dari tanggapan responden dalam tabel-tabel yang disajikan sebagai berikut:

Tabel 4.9

Tabulasi frekuensi pekerjaan dapat diselesaikan tepat waktu

\begin{tabular}{|l|l|l|l|l|}
\hline \multicolumn{2}{|l|}{ Pendapat } & Frekuensi & Skor & Persentase \\
\hline 5 & Sangat Setuju & 1 & 5 & $1,0 \%$ \\
\hline 4 & Setuju & 39 & 156 & $39,8 \%$ \\
\hline 3 & Cukup Setuju & 51 & 153 & $52,04 \%$ \\
\hline 2 & Tidak Setuju & 7 & 14 & $7,1 \%$ \\
\hline 1 & Sangat Tidak Setuju & 0 & 0 & $0,0 \%$ \\
\hline & Jumlah & 98 & 328 & $100 \%$ \\
\hline
\end{tabular}

Sumber :Hasil pengolahan data, 2013

Berdasarkan tabel 4.9 di atas dapat dideskripsikan tentang pendapat responden mengenai : pekerjaan dapat diselesaikan tepat waktu yakni sebanyak 1,0\% menyatakan sangat setuju, 39,8\% setuju, 52,04\% cukup setuju dan 7,1\% tidak setuju. Skor total 328 berada pada rentang skala cukup tinggi, sehingga dapat dikatakan bahwa disiplin di Satuan Polisi Pamong Praja Kabupaten Karawang dalam aspek pekerjaan dapat diselesaikan tepat waktu, berada dalam kondisi cukup tinggi.

Tabel 4.10

Tabulasi frekuensi datang di kantor sesuai jam masuk kerja 


\begin{tabular}{|l|l|l|l|l|}
\hline \multicolumn{2}{|l|}{ Pendapat } & Frekuensi & Skor & Persentase \\
\hline 5 & Sangat Setuju & 1 & 5 & $1,0 \%$ \\
\hline 4 & Setuju & 43 & 172 & $43,9 \%$ \\
\hline 3 & Cukup Setuju & 49 & 147 & $50.0 \%$ \\
\hline 2 & Tidak Setuju & 5 & 10 & $5,1 \%$ \\
\hline 1 & Sangat Tidak Setuju & 0 & 0 & 0 \\
\hline & Jumlah & 98 & 334 & $100 \%$ \\
\hline
\end{tabular}

Sumber :Hasil pengolahan data, 2013

Berdasarkan tabel 4.10 di atas dapat dideskripsikan tentang pendapat responden mengenai : datang di kantor sesuai jam masuk kerja, yakni sebanyak 1,0\% menyatakan sangat setuju, 43,9\% menyatakan setuju, 50,0\% cukup setuju dan 5,1\% tidak setuju. Skor total 334 berada pada rentang skala tinggi, sehingga dapat dikatakan bahwa disiplin di Satuan Polisi Pamong Praja Kabupaten Karawang dalam aspek datang di kantor sesuai jam masuk kerja berada dalam kondisi yang tinggi.

Tabel 4.11

Tabulasi frekuensi pulang dari kantor setelah jam kerja selesai

\begin{tabular}{|l|l|l|l|l|}
\hline \multicolumn{2}{|l|}{ Pendapat } & Frekuensi & Skor & Persentase \\
\hline 5 & Sangat Setuju & 7 & 35 & $7,1 \%$ \\
\hline 4 & Setuju & 19 & 76 & $19,4 \%$ \\
\hline 3 & Cukup Setuju & 60 & 180 & $61,22 \%$ \\
\hline 2 & Tidak Setuju & 12 & 24 & $12,2 \%$ \\
\hline 1 & Sangat Tidak Setuju & 0 & 0 & $0 \%$ \\
\hline & Jumlah & 98 & 315 & $100 \%$ \\
\hline
\end{tabular}

Sumber :Hasil pengolahan data, 2013

Berdasarkan tabel 4.11 di atas dapat dideskripsikan tentang pendapat responden mengenai : pulang dari kantor setelah jam kerja selesai, yakni sebanyak 7,1\% menyatakan sangat setuju, 19,4\% menyatakan setuju, 61,22\% cukup setuju dan 12,2\% tidak setuju. Skor total 315 berada pada rentang skala cukup tinggi, sehingga dapat dikatakan bahwa disiplin di Satuan Polisi Pamong Praja Kabupaten Karawang dalam aspek membuat pulang dari kantor setelah jam kerja selesai, berada dalam kondisi cukup tinggi.

Dari hasil analisis deskriptif terdapat 4 indikator (26.7\%) dimana responden menyatakan kriteria tinggi, hal ini menunjukan bahwa adanya persepsi yang lebih positif terhadap indikator tersebut. Sedangkan sisanya sebanyak 11 indikator (73.3\%) menyatakan kriteria cukup tinggi. Sehingga secara umum dapat dikatakan bahwa disiplin pada Satuan Polisi Pamong Praja Kabupaten Karawang cenderung dalam kondisi cukup tinggi. Seperti yang terlihat pada gambar 4.1 di bawah ini. 




\section{Gambar 4.1}

\section{Bar Scale Disiplin $\left(\mathrm{X}_{1}\right)$}

Indikator yang menunjukkan bahwa kondisi disiplin yang cukup tinggi, tiga indikator merupakan dimensi ketepatan waktu, empat indikator merupakan dimensi kepatuhan terhadap peraturan dan empat indikator merupakan dimensi kesadaran dalam bekerja. Hal ini menunjukkan bahwa disiplin pegawai Satuan Polisi Pamong Praja Kabupaten Karawang dalam aspek ketepatan waktu, kepatuha terhadap peraturan dan kesadaran dalam bekerja masih perlu ditingkatkan.

\section{Motivasi Kerja}

Gambaran mengenai motivasi kerja Satuan Polisi Pamong Praja Kabupaten Karawang dapat dilihat dari tanggapan responden dalam tabel-tabel berikut:

\section{Tabel 4.25}

\section{Tabulasi frekuensi hadir ditempat kerja setiap hari kerja}

\begin{tabular}{|l|l|l|l|l|}
\hline \multicolumn{2}{|l|}{ Pendapat } & Frekuensi & Skor & Persentase \\
\hline 5 & Sangat Setuju & 18 & 90 & $18,4 \%$ \\
\hline 4 & Setuju & 25 & 100 & $25,5 \%$ \\
\hline 3 & Cukup Setuju & 43 & 129 & $43,88 \%$ \\
\hline 2 & Tidak Setuju & 12 & 24 & $12,2 \%$ \\
\hline 1 & Sangat Tidak Setuju & 0 & 0 & $0 \%$ \\
\hline & Jumlah & 98 & 343 & $100 \%$ \\
\hline
\end{tabular}

Sumber :Hasil pengolahan data, 2013

Berdasarkan tabel 4.25 di atas dapat dideskripsikan tentang pendapat responden mengenai : hadir ditempat kerja setiap hari kerja, yakni sebanyak 18,4\% menyatakan sangat setuju, 25,5\% menyatakan setuju, 43,88\% menyatakan cukup setuju dan 12,2\% menyatakan tidak setuju. Skor total 343 berada pada rentang skala tinggi. Hal ini menunjukkan bahwa motivasi kerja di Satuan Polisi Pamong Praja Kabupaten Karawang dalam aspek hadir ditempat kerja setiap hari kerja, berada dalam kondisi yang tinggi. Sedangkan sisanya 
sebanyak 7 indikator (46.7\%) menyatakan kriteria cukup tinggi. Sehingga secara umum dapat dikatakan bahwa motivasi kerja pada Satuan Polisi Pamong Praja Kabupaten Karawang cenderung dalam kondisi yang tinggi. Seperti yang terlihat pada gambar 4.2 di bawah ini.

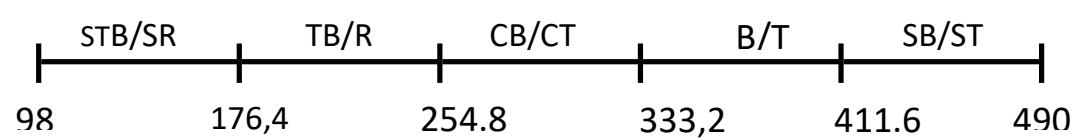

\section{Gambar 4.2}

\section{Bar Scale Motivasi Kerja $\left(\mathbf{X}_{2}\right)$}

Indikator yang menyatakan kriteria cukup tinggi lima diantaranya merupakan dimensi prestasi dan pengembangan diri. Hal ini menunjukkan bahwa motivasi kerja pegawai Satuan Polisi Pamong Praja dalam aspek prestasi dan pengembangan diri masih perlu ditingkatkan.

\section{Kinerja Satuan Polisi Pamong Praja Kabupaten Karawang}

Gambaran mengenai kinerja Satuan Polisi Pamong Praja Kabupaten Karawang dapat dilihat dari tanggapan responden dalam tabel-tabel yang disajikan sebagai berikut:

\section{Tabel 4.41}

Tabulasi frekuensi hasil pekerjaan yang pegawai lakukan sesuai target

\begin{tabular}{|l|l|l|l|l|}
\hline \multicolumn{2}{|l|}{ Pendapat } & Frekuensi & Skor & Persentase \\
\hline 5 & Sangat Setuju & 15 & 75 & $15,3 \%$ \\
\hline 4 & Setuju & 35 & 140 & $35,7 \%$ \\
\hline 3 & Cukup setuju & 40 & 120 & $40,8 \%$ \\
\hline 2 & Tidak Setuju & 8 & 16 & $8,2 \%$ \\
\hline 1 & Sangat Tidak Setuju & 0 & 0 & 0 \\
\hline & Jumlah & 98 & 351 & $100 \%$ \\
\hline
\end{tabular}

Sumber :Hasil pengolahan data, 2013

Berdasarkan tabel 4.41 di atas dapat dideskripsikan tentang pendapat responden mengenai : hasil pekerjaan yang pegawai lakukan sesuai target, yakni sebanyak 15,3\% menyatakan sangat setuju, 35,7\% menyatakan setuju, 40,8\% menyatakan cukup setuju, dan 8,2\% menyatakan tidak setuju. Skor total 351 berada pada rentang skala tinggi. Hal ini menunjukkan bahwa kinerja pegawai Satuan Polisi Pamong Praja Kabupaten Karawang 
dalam aspek hasil pekerjaan yang pegawai lakukan sesuai target berada dalam kondisi yang tinggi.

Sehingga secara umum dapat dikatakan bahwa kinerja pegawai pada Satuan Polisi Pamong Praja Kabupaten Karawang cenderung dalam kondisi yang tinggi. Seperti yang terlihat pada gambar 4.3 di bawah ini.

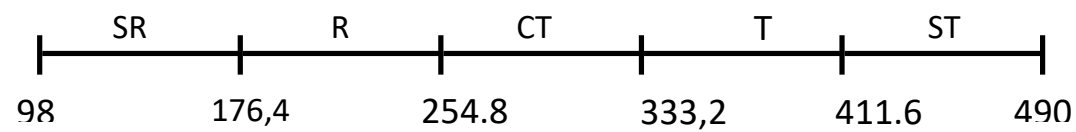

\section{Gambar 4.3}

\section{Bar Scale Kinerja Pegawai (Y)}

Indikator yang menyatakan kriteria cukup tinggi lima diantaranya merupakan dimensi inisiatif dan kerjasama sehingga hal ini menunjukkan bahwa pada dimensi tersebut kinerja pegawai Satuan Polisi Pamong Praja Kabupaten Karawang masih perlu ditingkatkan.

\subsubsection{Analisis Korelasi Disiplin dan Motivasi Kerja}

Tabel dibawah ini menunjukkan bahwa hasil perhitungan korelasi dengan model 2tailed atau dua sisi diperoleh hubungan antara variabel disiplin dengan motivasi kerja.

Tabel 4.58

Korelasi Bi-Variate

\begin{tabular}{|ll|l|l|}
\hline & & disiplin & Motivasi kerja \\
\hline Disiplin & Pearson Correlation & 1 &, $663(* *)$ \\
& Sig. (2-tailed) & &, 000 \\
& $\mathrm{~N}$ & 98 & 98 \\
Motivasi kerja & Pearson Correlation &, $663(* *)$ & 1 \\
& Sig. (2-tailed) &, 000 & \\
& $\mathrm{~N}$ & 98 & 98 \\
$* *$ Correlation is significant at the 0.01 level (2-tailed). &
\end{tabular}

\subsection{Pembahasan Hasil Penelitian}

\subsubsection{Deskriptif}

Berdasarkan hasil penelitian yang telah dikemukakan sebelumnya, maka dapat dibahas untuk analisis deskriptif adalah sebagai berikut :

1. Disiplin pada Satuan Polisi Pamong PrajaKabupaten Karawang berada pada skala cukup tinggi. Berdasarkan tabel 4.26 di atas, dari hasil analisis deskriptif terdapat 4 
indikator dimana responden menyatakan kriteria tinggi, hal ini menunjukan bahwa adanya persepsi yang lebih positif terhadap indikator tersebut. Sedangkan sisanya sebanyak 11 indikator menyatakan kriteria cukup tinggi. Sehingga secara umum dapat dikatakan bahwa disiplin pada Satuan Polisi Pamong Praja Kabupaten Karawang berada dalam kondisi cukup tinggi. Indikator yang menunjukkan bahwa kondisi disiplin yang cukup tinggi, tiga indikator merupakan dimensi ketepatan waktu, empat indikator merupakan dimensi kepatuhan terhadap peraturan dan empat indikator merupakan dimensi kesadaran dalam bekerja. Hal ini menunjukkan bahwa disiplin pegawai Satuan Polisi Pamong Praja Kabupaten Karawang dalam aspek ketepatan waktu, kepatuhan terhadap peraturan dan kesadaran dalam bekerja masih perlu ditingkatkan.

2. Dari analisis deskriptif indikator terdapat 7 indikator dimana responden menyatakan kriteria setuju, hal ini menunjukan bahwa adanya persepsi yang lebih positif terhadap indikator tersebut. Sedangkan sisanya sebanyak 10 indikator menyatakan kriteria cukup setuju. Sehingga secara umum dapat dikatakan bahwa disiplin pada Satuan Polisi Pamong Praja Kabupaten Karawang berada dalam kondisi cukup setuju. Indikator yang menunjukkan bahwa kondisi kepemimpinan yang cukup setuju, empat diantaranya merupakan dimensi pemimpin sebagai perancang yaitu pada aspek peran pimpinan dalam merancang program, peran pimpinan dalam membuat keputusan dengan tepat dan cepat, peran pimpinan dalam mengembangkan kreativitas organisasi, dan pimpinan setuju dalam hal inovasi dalam merancang program kerja. Hal ini menunjukkan persepsi yang cukup setuju dari pegawai terhadap disiplin di Satuan Polisi Pamong Praja Kabupaten Karawang dalam aspek pemimpin sebagai perancang.

3. Motivasi kerja pada Satuan Polisi Pamong Praja Kabupaten Karawang berada pada skala tinggi. Berdasarkan analisis deskriftif terdapat 8 indikator dimana responden menyatakan kriteria tinggi, hal ini menunjukan bahwa adanya persepsi yang lebih positif terhadap indikator tersebut. Sedangkan sisanya sebanyak 7 indikator menyatakan kriteria cukup tinggi. Sehingga secara umum dapat dikatakan bahwa motivasi kerja pada Satuan Polisi Pamong Praja Kabupaten Karawang berada dalam kondisi yang tinggi. Indikator yang menyatakan kriteria cukup tinggi lima diantaranya merupakan dimensi prestasi dan pengembangan diri. Hal ini menunjukkan bahwa motivasi kerja pegawai Satuan Polisi Pamong Praja dalam aspek prestasi dan 
pengembangan diri masih perlu ditingkatkan. Indikator tersebut diantaranya adalah : mengisi daftar hadir sesuai dengan jam kedatangan, berusaha keras untuk memperlihatkan prestasi kerja yang baik, bekerja keras untuk mencapai target yang diberikan, mampu menyelesaikan masalah yang dihadapi, mengikuti setiap pelatihan yang diadakan oleh lembaga untuk meningkatkan kemampuan dan keterampilan, dan pegawai selalu berusaha meningkatkan kemampuan diri untuk hasil kerja yang terbaik.

\section{Kesimpulan}

Berdasarkan hasil penelitian dan pembahasan, penulis dapat memberikan kesimpulan sebagai berikut :

1. Disiplin pegawai Satuan Polisi Pamong Praja Kabupaten Karawang berada pada skala cukup tinggi.

2. Motivasi Kerja pegawai Satuan Polisi Pamong Praja Kabupaten Karawang berada pada skala tinggi.

3. Kinerja Pegawai Satuan Polisi Pamong Praja Kabupaten Karawang berada pada skala tinggi.

4. Terdapat hubungan korelasional yang positif antara disiplin dan motivasi kerja.

5. Terdapat pengaruh parsial disiplin dan motivasi kerja terhadap kinerja pegawai Satuan Polisi Pamong Praja Kabupaten Karawang

6. Terdapat pengaruh secara simultan disiplin dan motivasi kerja terhadap kinerja pegawai Satuan Polisi Pamong Praja Kabupaten Karawang.

\subsection{Saran}

Berdasarkan hasil penelitian dan pembahasan, penulis dapat memberikan saran sebagai berikut :

1. Satuan Polisi Pamong Praja Kabupaten Karawang, diharapkan mampu meningkatkan disiplin pegawainya terutama dalam aspek dimensi ketepatan waktu dan kesadaran dalam bekerja terutama dalam hal jam kerja dan melaksanakan tugas sesuai dengan yang direncanakan serta mengevaluasinya diantaranya melalui penggunaan absensi elektronik, pelatihan dan pendidikan tentang kepemimpinan yang berkesinambungan, mengadakan rapat koordinasi secara rutin dan terarah. 
2. Satuan Polisi Pamong Praja Kabupaten Karawang, diharapkan mampu mempertahankan tingkat motivasi kerja yang sudah baik dan meningkatkan motivasi kerja pegawainya dalam hal pemenuhan target hasil pekerjaan, tanggung jawab pegawai dalam menyelesaikan tugas, tingkat perhatian dari atasan terhadap bawahannya, saling membantu dengan rekan kerja yang sedang kesulitan dalam pekerjaannya, kepuasan kerja dari sesama pegawai, dan kepuasan terrhadap hasil pekerjaan yang sukar. Diantaranya melalui program pemberian penghargaan terhadap pegawai yang berprestasi, sharing tentang permasalahan pekerjaan, mengadakan rekreasi bersama seluruh pegawai, dan mengadakan program outbond sehingga diharapkan meningkatnya kerjasama diantara pegaawai.

3. Satuan Polisi Pamong Praja Kabupaten Karawang, diharapkan mampu meningkatkan kinerja pegawainya dengan memperbaiki dan meningkatkan pegawai bekerja dengan waktu yang efektif dan efisien, hubungan dengan pimpinan terjalin dengan baik, hubungan dengan rekan kerja terjalin dengan baik, hubungan dengan pelanggan terjalin dengan baik, pegawai memiliki pengetahuan bidang teknis yang dikerjakan, pegawai mengetahui prosedur kerja terbaru, hasil pekerjaan yang pegawai lakukan sesuai target dan berani menerima resiko kesalahan yang dilakukan. Diantaranya melalui program diklat, memberikan hukuman secara adil terhadap pegawai yang melanggar peraturan, dan memberikan informasi yang detail setiap uraian pekerjaan.

4. Mengoptimalkan kinerja pegawai Satuan Polisi Pamong Praja Kabupaten Karawang, melalui program atau kebijakan yang berkaitan dengan disiplin, diantaranya yaitu, penggunaan absensi elektronik (hand reader), pemberian hukuman bagi pegawai yang indsipliner, pemberian penghargaan bagi pegawai teladan dalam hal jam kerja. .

5. Mengoptimalkan kinerja Satuan Polisi Pamong Praja Kabupaten Karawang, melalui program atau kebijakan yang berkaitan dengan motivasi kerja diantaranya dengan pemilihan pegawai berprestasi, menerapkan reward and punishment, dan lain-lain.

6. Adanya kajian atau penelitian lebih lanjut tentang variabel lainnya yang mempengaruhi variabel kinerja Satuan Polisi Pamong Praja Kabupaten Karawang, sehingga diharapkan fungsi dan sistem manajemen dapat berjalan lebih optimal diantaranya variabel peran kepemimpinan, budaya organisasi, kompetensi, kepuasan kerja, dan lain-lain. 


\section{Daftar Pustaka}

Arikunto, Suharsimi. 2006. Prosedur Penelitian. Jakarta : Rineka Cipta

Ebuara, VO. 2012. Influence of Staff Discipline and Attitude to Work On Job Satisfaction Lecturers in Tertiary Institutions in Cross River State. Public Policy and Administration Research (www.iiste.org). Vol.2, No.3, 2012

Gusmana, Agus. 2008. Pengaruh Budaya Organisasi, Disiplin Kerja dan Motivasi Kerja terhadap Kinerja Aparat Kecamatan Batujajar Kabupaten Bandung Barat. Tesis. Program Pascasarjana Magister Manajemen. Sekolah Tinggi Ilmu Ekonomi Pasundan. Handoko, Hani T. 2001. Manajemen Personalia dan Sumber Daya Manusia. Yogyakarta. BPFE.

Handayaningsih. 2006. Pengaruh Kepemimpinan, Motivasi, Disiplin Kerja dan Pengawasan Terhadap Produktivitas Kerja Pegawai Kecamatan Wilayah Kabupaten Wonogiri. Tesis. Universitas Muhammadiyah Surakarta.

Heidjarachman dan Husnan. 2002. Manajemen Personalia. Yogyakarta : BPFE.

Hidayat D. 2012. Pengaruh Kepemimpinan, dan Motivasi Kerja terhadap Kinerja Karyawan PT KIA. Tesis. Program Pascasarjana Magister Manajemen. Universitas Singaperbangsa Karawang.

Iskandar, O. 2002. Etos Kerja, Motivasi, dan Sikap inovatif terhadap Produkstivitas Petani. Jurnal Makara Sosial Humaniora Vol. 6 No 1. Program Pascasarjana. Universitas Negeri Jakarta.

Kuswanda, Uus. 2006. Pengaruh Kemampuan Kerja, Motivasi Kerja dan Disiplin Kerja terhadap Kinerja Pegawai Biro Dekonsentrasi dan Tugas Perbantuan SETDA Provinsi Jawa Barat. Tesis. Program Pascasarjana Magister Manajemen. Sekolah Tinggi Ilmu Ekonomi Pasundan.

Mangkunegara, Anwar. P. 2009. Manajemen Sumber daya Manusia Perusahaan. (cetakan ke-9). Bandung: PT. Remaja Rosda Karya Offset.

Mangkunegara, Anwar. P. 2010. Evaluasi Kinerja SDM. Cetakan keempat. Bandung: PT. Refika Aditama

Nawawi, H., 2006.Evaluasi dan Manajemen Kinerja di Lingkungan Perusahaan dan Industri.(cetakan ke-1). Yogyakarta: Gadjah Mada University Press

Riduwan dan Kuncoro, Engkos Achmad. 2008. Cara Menggunakan dan Memaknai Analisis Jalur (Path Analysis). Cetakan Kedua. Bandung: Alfabeta. 
Ridwan, A F. 2012. Pengaruh Kepemimpinan dan Disiplin Kerja terhadap Kinerja Guru.

Tesis. Program Pascasarjana Magister Manajemen. Universitas Singaperbangsa Karawang.

Sedarmayanti. 2010. Manajemen Sumber Daya Manusia Reformasi Birokrasi dan Manajemen Pegawai Negeri Sipil.Cetakan keempat. Bandung : PT. Refika Aditama

Siagian, Sondang. 2009. Kiat Meningkatkan Produktivitas Kerja. Jakarta: PT. Rineka Cipta.

Sugiyono, 2010, Metode Penelitian Administrasi, Bandung: Alfabeta

Sumarna, E. 2007. Pengaruh Disiplin dan Kepuasan Kerja Pegawai terhadap Kinerja Kantor di Lingkungan Kandepag Kabupaten Karawang. Tesis. Program Pascasarjana Magister Manajemen. Sekolah Tinggi Ilmu Ekonomi Pasundan.

Suradinata, Ermaya. 1997. Pemimpin dan Kepemimpinan Pemerintah. Jakarta:

PT. Gramedia.

Uno, H.B. 2009. Teori Motivasi dan Pengukurannya. Cetakan kelima. Jakarta: Bumi Aksara.

Wahyuningrum. 2008. Hubungan Kemampuan, Kepuasan dan Disiplin Kerja dengan Kinerja Pegawai di Kecamatan tanggungharjo Kabupaten Grobogan. Tesis. Program Pascasarjana Magister Ilmu Administasi. Universitas Diponegoro Semarang.

Wibowo. 2010. Manajemen Kinerja Cetakan ketiga.. Jakarta: PT. Raja Grafindo Perkasa

Widyaningrum, ME. 2011. Influence of Motivation and Culture on Organizational Commitmen and Performance of Employee of Medical Services. Academic Research International. Vol. 1 Issue 3.

Zaeni, A. 2012. Pengaruh Disiplin, dan Motivasi Kerja terhadap Kinerja Pegawai Kantor Urusan Agama Kabupaten Karawang. Tesis. Program Pascasarjana Magister Manajemen. Universitas Singaperbangsa Karawang.

www.realita-news.com, dilihat tanggal 7 september 2013 